\title{
Effect of Aqueous Allium Cepa Extract from Red Onion on Aluminum Chloride- Induced Anemia in Female Rats
}

\author{
*11 IGE, SF ; ${ }^{2}$ AIYEOLA, A \\ ${ }^{I}$ Department of Physiology, Faculty of Basic Medical Sciences, College of Health Sciences, Ladoke Akintola University of Technology, \\ P.M.B.4000, Ogbomoso, Oyo State, Nigeria. \\ ${ }^{2}$ Department of Physiology, Faculty of Basic Medical Sciences, College of Medicine, University of Ibadan, Nigeria \\ *corresponding author: Email: sfige@lautech.edu.ng; funkeige2006@yahoo.com +2348060743616
}

\begin{abstract}
This study examined the protective effect of Allium cepa extract from red onion on aluminum induced anemia in female wistar rats. Twenty-four animals (six rats per group) were used for this study. They were divided into four groups: group one served as control, group two animals were treated with $100 \mathrm{mg} / \mathrm{kg} \mathrm{BW}$ of aluminum chloride and served as Aluminum chloride $\left(\mathrm{AlCl}_{3}\right)$ group, group three, Allium cepa alone group were treated with $1 \mathrm{~mL} / 100 \mathrm{~g} \mathrm{BW}$ of Allium cepa while group four was simultaneously treated with $1 \mathrm{~mL} / 100 \mathrm{~g} \mathrm{BW}$ of Allium cepa and $100 \mathrm{mg} / \mathrm{kg} \mathrm{BW} \mathrm{AlCl}_{3}$. Treatments lasted for 4 weeks. Red blood cells (RBC), packed cell volume $(\mathrm{PCV})$, Hemoglobin concentration $(\mathrm{Hb})$ were measured from blood sample collected from each rat. Serum urea, serum and kidney malondialdehyde (index of lipid peroxidation) and kidney catalase and superoxide dismutase (SOD) activities were measured spectrophotometrically. Significant decrease in RBC, PCV, Hb, catalase, SOD and significant increase in serum urea and malondialdehyde were observed in aluminum treated animals when compared with control. Animals treated with Allium cepa alone had significant increase in PCV, Hb, SOD and significant decrease in malondialdehyde and serum urea while there was no significant different in RBC and catalase when compared with control. Simultaneous treatment of the animals with Allium cepa and aluminum chloride resulted in significant increase in PCV while there was no significant different in $\mathrm{RBC}, \mathrm{Hb}$, catalase, malondialdehyde when compared with control.This study reveals that Allium cepa extract treatment ameliorate aluminum-induced anemia through antioxidant system.
\end{abstract}

\section{DOI: https://dx.doi.org/10.4314/jasem.v21i7.11}

Copyright (c) 2017 Ige and Aiyeola. This is an open access article distributed under the Creative Commons Attribution License (CCL), which permits unrestricted use, distribution, and reproduction in any medium, provided the original work is properly cited

Received 16 October 2017; received in revised form 11 November 2017; accepted 14 December 2017

Keywords: Anemia, Allium cepa, Aluminum chloride, lipid peroxidation.

Anemia, one of blood disorders, is a fall in the total amount of red blood cell and hemoglobin in the blood, characterize with decrease oxygen carrying ability of blood (Rodak, 2007). Anemia being the most common blood disorder affecting large number of world population (Janz et al., 2013), resulted in death in not less than 183,000 in 2013 (Global Burden of Disease Study, 2013) with highest prevalence rate in women (Vos et al., 2012). Anemia occurs when the rate of production of mature red blood cells does not keep pace with rate of its destruction. Decrease/impair red blood cell production is one of the main causes of anemia.

Aluminum (Al) is one of the toxic trace elements, to both humans and animals. Humans are exposed to aluminum through diet (salt, herbs, spices, corn etc.) (Yousef, 2004), drinking water, cosmetics, cookware utensils, containers, antacids, vaccines and tooth paste (Abbasali et al., 2005). There is no known physiological role of aluminum in the living tissues; however, exposure to excess aluminum produces adverse physiological effects. Aluminum is a known environmental toxicant that can cause neurological diseases (Yousef, 2004), reproductive dysfunctions such as, damage of the ovarian structure, ovulation inhibition and testicular dysfunction (Wang et al., 2012; Fu et al., 2014; Ighodaro et al., 2012). It is also known to induce anemia (Mahieu et al., 2000). Reduction in erythropoietin synthesis and secretion, and inhibition of intestinal absorption of iron has been proposed as mechanisms of aluminum-induced anemia (Kalaiselvi et al., 2015) with increase hemolysis and reduce heme and globulin syntheses reported due to aluminum toxicity. Uremia is usually seen with aluminum-hematotoxicity (Mahieu et al., 2000). Likewise, cardiovascular diseases, cognitive impairment and reduction in quality of life are associated with anemia in kidney diseases (Wang et al., 2012). Erythropoietin deficiency is the predominant cause of anemia in kidney diseases (Babitt and Lin, 2012) due to the fact that kidney is the main source of erythropoietin. So also, oxidative stress has been implicated in the genesis and progression of kidney diseases (Jha et al., 2016), long-chain polyunsaturated fatty acids present in the kidney enhance the oxidative stress-induced kidney disease.

Allium cepa is a potent antioxidant (Ige et al., 2017), reported to protect against aluminum-induced reproductive dysfunction (Ige and Akhigbe, 2012) and cadmium-induced nephrotoxicity (Ige et al., 2011). Many studies have been carried out on the effects of Allium cepa on blood parameters (Enitan et al., 2012; Nwaehujo et al., 2014; Jaiswal et al., 
2013). Enitan et al., reported significant increase in packed cell volume, red blood cell count and hemoglobin concentration (Enitan et al., 2012). Increase red blood cells membrane stability and attenuation of $\mathrm{HgCl}_{2}$-induced oxidative stress in rats erythrocytes was also reported (Nwaehujo et al., 2014; Jaiswal et al., 2013). In view of all these findings, there is a dearth of information on the effect of Allium cepa on the aluminum-induced anemia. Therefore, this study was carried out to examine the effect of Allium cepa extract on aluminum chloride induced anemia.

\section{MATERIALS AND METHODS}

Animals: Twenty four adult female wistar rats weighing 150-200g were used for this study. Animals were kept in research section of the animal house of Department of Physiology, Ladoke Akintola University of Technology, Ogbomoso, Nigeria. They were fed with standard diet ad libitum and divided into four groups of six rats each: group one served as control, group two animals were treated with $100 \mathrm{mg} / \mathrm{kg} \mathrm{BW}$ of aluminum chloride and served as Aluminum chloride $\left(\mathrm{AlCl}_{3}\right)$ group, group three, Allium cepa alone group were treated with $1 \mathrm{~mL} / 100 \mathrm{~g}$ BW of Allium cepa while group four was simultaneously treated with $1 \mathrm{~mL} / 100 \mathrm{~g}$ BW of Allium cepa and $100 \mathrm{mg} / \mathrm{kg} \mathrm{BW} \mathrm{AlCl}_{3}$. The treatments were given daily, orally for 28 days. Animals were cared for according to United States National Institute of Health Guidelines for the Care and Use of Laboratory Animals (NIH publication No 85-23).

Allium cepa extract preparation: Allium cepa was prepared following previous study procedure (Ige and Akhigbe, 2013). Allium cepa (red onion) bulbs purchased from local market in Ogbomoso, Oyo state, Nigeria, were rinsed thoroughly in distilled water, air dried, and $200 \mathrm{~g}$ was then blended. The resulting paste was allowed to stand for $24 \mathrm{~h}$. Juice was then filtrated and squeezed out of it using a tight sieve. The filtrate/juice was prepared on weekly basis following the same procedure and kept at $4^{\circ} \mathrm{C}$ to prevent it from losing its potency.

Hematological parameters measurements: Blood samples were collected by cardiac puncture and divided into two; one half in plain bottles and the other in ethylene diamine tetra-acetic acid (EDTA) bottles, plasma and serum were obtained by centrifuge at $3000 \mathrm{rpm}$ for 20 minutes.

PCV was determined using microhaematocrite method, RBC counts were determined using haemocytometer method, haemoglobin determination was by cyanmethaemoglobin method. Serum urea and malondialdehyde concentration were determined spectrophotometrically using Berthelot enzymatic colorimetric method (Kaplan, 1984) and Varshney and Kale, (1990) method, respectively.
Determination of kidney antioxidant and lipid peroxidation status: After animals were sacrificed at end of the experimental period, kidney of each rat was dissected and homogenized in phosphate buffer, centrifuge at $4000 \mathrm{rpm}$ for 10 minutes. The supernatants collected were used for the biochemical analyses. Malondialdehyde concentration, catalase and superoxide dismutase activities were determined as described in previous studies (Varshney and Kale, (1990); Sinha, (1972); Fridovich, (1986) respectively.

Statistical analysis: All values were reported as mean \pm S.E.M. One-way analysis of variance (ANOVA) was used to analyze for the significance of differences between means followed by unpaired Student's $t$-test using Microsoft excel. Values of $P<$ 0.05 were considered statistically significant.

\section{RESULTS AND DISCUSION}

Red blood cells counting (RBC), hemoglobin concentration $(\mathrm{Hb})$ and packed cell volume $(\mathrm{PCV})$ are part of hematological parameters usually employed to diagnose effects of toxic substances exposure. RBC, hematocrit and $\mathrm{Hb}$ are use to determine anemia while low $\mathrm{Hb}$ has been linked with increase mortality and morbidity rate (Aletan, 2014). In the present study, treatment of animals with aluminum chloride significantly decreased the blood parameters: RBC, $\mathrm{PCV}$ and $\mathrm{Hb}$. Animals treated with Allium cepa alone had significant increase in PCV and Hemoglobin concentration when compared with control. Simultaneous treatment of the animals with Allium cepa and aluminum chloride resulted in significant increase in PCV when compared with control, while there was no significant different in $\mathrm{RBC}$ and $\mathrm{Hb}$, (Table 1).

Table 1: Effect of Allium cepa on some blood parameters of aluminum treated rats

\begin{tabular}{lllll}
\hline Parameters & Control & Al & Allium cepa & $\begin{array}{l}\text { Al + Allium } \\
\text { cepa }\end{array}$ \\
\hline $\begin{array}{l}\text { RBC } \\
\left(\mathbf{m L} / \mathbf{m m}^{3}\right)\end{array}$ & $6.96 \pm 0.66$ & $5.18 \pm 0.184^{*}$ & $8.37 \pm 0.129$ & $7.78 \pm 0.20$ \\
$\mathbf{H b}(\mathbf{g} \%)$ & $12.7 \pm 0.73$ & $10.64 \pm 0.50^{*}$ & $17.28 \pm 0.64^{*}$ & $13.76 \pm 0.48$ \\
$\mathbf{P C V}(\%)$ & $44.4 \pm 1.33$ & $40.0 \pm 0.71^{*}$ & $53.4 \pm 1.12^{*}$ & $49.0 \pm 1.41^{*}$ \\
\hline${ }^{*} \mathrm{p}<0.05$ vs control & & &
\end{tabular}

The reduction in red blood cells count, hemoglobin concentration and packed cell volume in animals treated with aluminum chloride observed in this study is in agreement with previous studies (Mahieu et al., 2000; Kalaiselvi et al., 2015). They reported that reduction in hemoglobin concentration and red blood cells count as a result of exposure to aluminum are a reflection of disrupt red blood cell synthesis. The study of Kalaiselvi et al., has also suggested that reduction in $\mathrm{RBC}$ and $\mathrm{Hb}$ due to aluminum exposure might be the result of erythropoiesis inhibition couple with increase hemolysis (Kalaiselvi et al., 2015). In our study, the reduction in RBC, PCV and $\mathrm{Hb}$ was ameliorated by treatment of the aluminum exposed rats with Allium cepa. 
Anemia is one of the major health problems, with about $30 \%$ world populations suffer from it (Iuchi, 2012). One of the causative factors of anemia is reactive oxygen species of erythrocyte, though iron deficiency is the most common causative factor (Iuchi, 2012). Alteration in trace elements especially zinc, copper and iron and lipid peroxidation in plasma and erythrocytes have also been suggested as mechanism of aluminum-induced anemia (Guo et al., 2004). Accumulation of aluminum can affect the iron and zinc concentration of a tissue (Domingo, et al. 1993; Jia et al, 2001) thereby decreases the antioxidant activities while lipid peroxidation increases. Iron and aluminum may also compete for absorption because both are transported by transferrin. Deloncle et al, (2001) study has demonstrated this where radio labeled iron absorption was inhibited by aluminum.

The study of Yousef, (2004) has also shown that aluminum chloride induces oxidative stress in rabbit organs with kidney inclusive. Oxidative stress has also been implicated in aluminum-induced organs/ tissues dysfunction and toxicity such as hepatotoxicity (Al-Qayim and Saadoon, 2013), reproductive toxicity (Ige et al., 2012; Kalaiselvi et al. 2014) and nephrotoxicity (Oda, 2016).

The present study reveals significant increase in serum and kidney malondialdehyde (an index of lipid peroxidation) and significant decrease in kidney catalase and SOD activities in aluminum alone treated rats, (Table 2 and Figure 1). The significant increase in malondialdehyde observed in the present study is in agreement with previous study of Oda, (2016) where administration of aluminum chloride resulted in increased serum malondialdehyde. Significant decrease in malondialdehyde and increase in kidney catalase and superoxide dismutase activities were observed in Allium cepa treated animals. Insignificant difference (compared to control) in malondialdehyde, catalase and superoxide dismutase activities of animals treated with aluminum and Allium cepa confirms the antioxidant effect of Allium cepa against aluminum chloride inducednephrotoxicity in this study. The present study also corroborates our previous studies where antioxidant property of Allium cepa against various organs toxicity induced by toxic substances (Ige et al, 2012; Ige et al 2017) which include kidney toxicity (Ige et al., 2011) were confirmed.

Table 2: Effect of Allium cepa on kidney antioxidant activities and lipid peroxidation status of aluminum treated rats

\begin{tabular}{lllll}
\hline Parameters & Control & $\mathrm{Al}$ & $\begin{array}{l}\text { Allium } \\
\text { cepa }\end{array}$ & $\begin{array}{l}\mathrm{Al}+\text { Allium } \\
\text { cepa }\end{array}$ \\
\hline SOD & $0.31 \pm 0.02$ & $0.19 \pm 0.01^{*}$ & $0.54 \pm$ & $0.24 \pm 0.01^{*+}$ \\
(U/g tissue) & & & $0.02^{*}$ & \\
Catalase & $0.0089 \pm$ & $0.0051 \pm$ & $0.014 \pm$ & $0.0080 \pm 0.001$ \\
(IU/g tissue) & 0.0012 & $0.0006^{*}$ & 0.002 & \\
MDA & $2.6 \pm 0.14$ & $3.4 \pm 0.18^{*}$ & $1.23 \pm$ & $2.13 \pm 0.31$ \\
(U/g tissue) & & & $0.27^{*}$ & \\
\hline * $\mathrm{p}<0.05$ vs control, $+\mathrm{p}<0.05 \mathrm{vs} \mathrm{Al}$ & & &
\end{tabular}

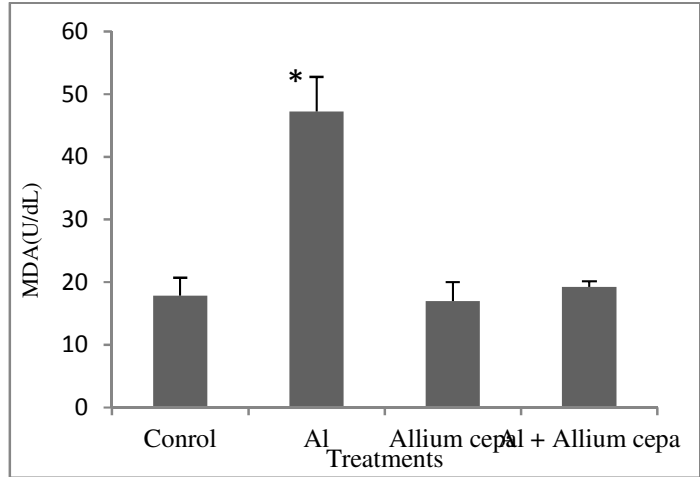

Fig 1: Effect of Alliumcepa on the serum lipid peroxidation of aluminum treated rats. $* \mathrm{p}<0.05$ vs control

Anemia can also be caused by diseases especially kidney diseases, some patients with kidney disease have been reported to develop anemia (Brugnara and Eckardt, 2011). Diseased or damaged kidneys don't produce sufficient erythropoietin which stimulates bone marrow to produce red blood cells (Winearls et $a l .$, 1986). Hematotoxic effect of aluminum has been observed to occur with renal damage manifested with uremia (Mahieu et al., 2000). In the present study serum urea was studied and it was found that aluminum exposure significantly increased serum urea (Figure 2). This is in consonance with Mahieu et al., (2000) study. The simultaneous treatment of aluminum exposed rats with Allium cepa mitigates the significant increase in serum urea (Figure 2).

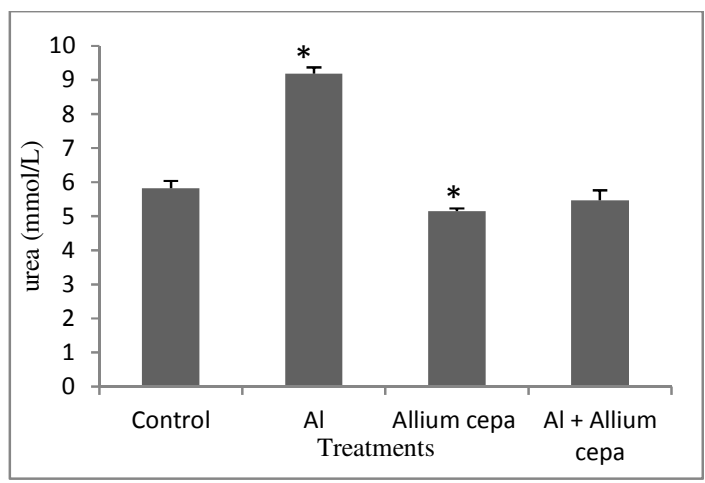

$*_{\mathrm{p}}<0.05$ vs control

Fig 2: Effect of Alliumcepa on the serum Urea of aluminum treated rats.

In conclusion, this study gives a vivid clarity that Allium cepa ameliorates aluminum-induced anemia and uremia associated with kidney damage from oxidative effect of aluminum.

\section{REFERENCES}

Abbasali, KM; Zhila, T;Farshad N (2005). Developmental toxicity of aluminium from high doses of $\mathrm{AlCl} 3$ in mice.J.Applied Res. 5: 575579 . 
Aletan, UI (2014). Hematological Effects Following Ingestion of Allium cepa (Onion), Allium sativum Garlic and Treatment with Iodine in Albino Wistar Rats. Pakistan Journal of Nutrition 13 (8): 457-461.

Al-Qayim, AJM; Saadoon, D. (2013). Assessment of the ameliorative role of proplis and malic acid in intestinal and liver functions of aluminum exposed male rats. Int J Sci Nat 4:552-558

Babitt, JL;Lin, HY (2012). Mechanisms of Anemia in CKD.J Am SocNephrol. 23(10): 1631-1634.

Brugnara, C; Eckardt, KU (2011).Hematologic aspects of kidneydisease. In: Taal MW, ed. Brenner and Rector's The Kidney. 9th ed. Philadelphia: Saunders: 2081-2120.

Deloncle, R; Huguet, F; Fernandez, B; Guillard, G (2001). Chronic administration of Maluminum and iron in young mature rat brain areas.Toxicol.lett. 104, 65-73.

Domingo, JL; Gomez, DJ; Sanchez, JM (1993). Effect of various dietary constituentson gastrointestinal absorption of aluminum from drinking water and diet. Res. Commun. Chem. Pathol. Pharmacol. 79: 377-80.

Enitan, SS; Ajeigbe, KO; Josiah, SJ; Ehiaghe, FA (2012). Haematological and Hepatotoxic Potential of Onion (Allium cepa) and Garlic (Allium sativum) Extracts in Rats. European Journal of Medicinal Plants, 2(4): 290-307.

Fridovich, I (1986). Superoxide dismutases.AdvEnzymelRelat Area MolBiol 58:61-97.

Fu, Y; Jia, FB; Wang, J; Song, M;Liu, SM; Li, YF; Liu, SZ; Bu, QW (2014). Effects of sub-chronic aluminum chloride exposure on rat ovaries.Life Sci. 100(1):61-6.

Global Burden of Disease Study (2013). Mortality and Causes of Death, Collaborators Global, regional, and national age-sex specific all-cause and cause-specific mortality for 240 causes of death, 1990-2013: a systematic analysis for the Global Burden of Disease Study 2013. Lancet.385 (9963): 117-71.

Guo, CH; Hsu, GS; Lin, LY; Wang, YH; Lin, CY; Yeh, MS (2004). Distribution patterns of trace metals and of lipid peroxidation in plasma and erythrocytes of rat exposed to aluminum. Biol Trace Elem Res., 101 (1): 61 - 71.

Ige, SF; Akhigbe, RE; Adewale, AA; Badmus, JA; Olaleye, SB; Ajao, FO; Saka, WA; Owolabi, OQ (2011). Effect of Allium cepa (onion) extract on cadmium- induced nephrotoxocity in rats. Kidney Research Journal 1 (1): 41-47.

Ige, SF; Akhigbe, RE (2012).The role Allium cepa on aluminum-induced reproductive dysfunction in experimental male rat models. Journal of Human Reproductive Sciences 5: 200-5.

Ige, SF; Akhigbe, RE (2013).Common onion (Allium cepa) extract reverses cadmium-induced organ toxicity and dyslipidaemia via redox alteration in rats. Pathophysiology, 20 :269-274

Ige, SF; Badmus, JA; Oyedokun, KA; Okeke, JC (2017). Reduction on organs cadmium retention in male rats: the role of Allium cepa. European Journal of Biomedical and Pharmaceutical Sciences 4(7): 29-34

Ighodaro, OM; Omole, JO; Ebuehi, OA; Salawu, FN (2012). Aluminium-induced liver and testicular damage: effects of Piliostigmathonningiimethanolic leaf extract. Nig Q J Hosp Med.22(3):158-63.

Iuchi, Y. 2012. Anemia Caused by Oxidative Stress. Anemia. Dr. Donald Silverberg (Ed.), ISBN: 978- 953-51-0138-3, InTech, Available from: http://www.intechopen.com/books/anemia/anemi a-caused-byoxidative-stress

Jaiswal, N; Kumar, D; Rizvi, SI (2013). Red onion extract (Allium cepa L.) supplementation improves redox balance in oxidatively stressed rats. Food Science and Human Wellness.2:(2): 99-104)

Janz, TG; Johnson, RL; Rubenstein, SD (2013). Anemia in the emergency department: evaluation and treatment.Emergency medicine practice. 15 (11): 1-15.

Jha, JC; Banal, C; Chow, BS; Cooper, ME; JandeleitDahm K (2016). Diabetes and Kidney Disease: Role of Oxidative Stress.Antioxid Redox Signal. 25(12):657-684.

Jia, Y; Zhong, C; Wang, Y; Zhao, R ( 2001). Effects of aluminum intake on the content of aluminum, iron, zinc and lipid peroxidation in the hippocampus of rats. Wei. Sheng. Yan Jiu. 30(3):132-4.

Kalaiselvi, A; Suganthy, OM; Govindassamy, P; Vasantharaja, D; Gowri, B; Ramalingam, V (2014). Influence of aluminum chloride on antioxidant system in the testis and epididymis of rats. Iranian J Toxicol 8 (24): 991-997.

Kalaiselvi, A; Aadhinaath, RG; Ramalingam, V (2015). Effect of Aluminium Chloride and Protective Effect of Ginger Extract on 
Hematological Profiles in Male Wistar Rats. Int. J. Pharm. Phytopharmacol. Res. 4 (4): 218-222.

Kaplan, AP (1984). Drug-induced skin disease. J. Allergy Clin. Immunol. 74 (4 Pt 2), 573-579.

Mahieu, S; del Carmen, CM; Gonzalez, M;Millen, N; Elias, MM (2000). Aluminum toxicity.Hematological effects.ToxicolLett. 111(3):235-42.

Nwaehujor, CO; Ode, JO; Nwinyi, FC; Asuzu, OV (2014). Allium cepa Linn. (Liliaceae) (red onion) bulb aqueous extract increases membrane stability of red blood cells and ameliorates oxidative stress in diabetes. Comparative Clinical Pathology. 23:1727-1731

Oda, SS (2016). The influence of Omega3 fatty acids supplementation against aluminuminducedtoxicity in male albino rats. Environ SciPollut Res 23(14):14354-61

Sinha, AK (1972). Colorimetric assay of catalase. Anal Biochem 47:389-94.

Varshney, R; Kale, RK (1990).Effects of calmodulin antagonists on radiation-induced lipid peroxidation in microsomes.Int $\mathrm{J}$ RadiatBiol 58:733-43.
Vos, T; Flaxman, AD; Naghavi, M; Lozano, R; Michaud, C; Ezzati, M; Shibuya, K; Salomon JA; et al. (2012). Years lived with disability (YLDs) for 1160 sequelae of 289 diseases and injuries 1990-2010: a systematic analysis for the Global Burden of Disease Study 2010. Lancet.380 (9859): 2163-96.

Wang, N; She, Y; Zhu, Y; Zhao, H; Shao, B; Sun, $\mathrm{H} ; \mathrm{Hu}, \mathrm{C} ; \mathrm{Li}, \mathrm{Y}$ (2012). Effects of subchronic aluminum exposure on the reproductive function in female rats. Biol Trace Elem Res. 145(3):3827.

Winearls, CG; Oliver, DO; Pippard, MJ; Ried, C; Downing, MR; Cotes, PM (1986). Effect of human erythropoietin derived from recombinant DNA on the anemia of patients maintained by chronic hemodialysis. Lancet 2: 1175-1178

Yousef, MI (2004). Aluminum-induced changes in hemato-biochemical parameters, lipid peroxidation and enzyme activities of male rabbits: protective role of ascorbic acid. Toxicol. 199:47-57. 